\title{
On Legal System of Stock Option
}

\author{
Ning Qingfang \\ School of Economic Law \\ Southwest University of Political Science and Law \\ Chongqing, 401120 China
}

\begin{abstract}
In recent years, with the improvement of company law, securities law, tax law and accounting standards, legal environment of stock option development has initially formed, and the rapid popularization and development period of stock option have come in China. In recognizing the important value of stock option, it needs to avoid the new moral hazard in stock option implementation process through perfecting legislation, establishing a healthy stock option system with incentive and constraint coexisting, in order to ensure the function of stock option system to effectively play, which is very necessary.
\end{abstract}

Keywords-stock option; company governance; incentive;

\section{Introduction}

In current enterprise operation and management, it generally exists the imbalance phenomenon of "more constraints, less excitation", "more spiritual encouragement and less material reward". Thus, how to establish a set of effective incentive mechanism to the operators has been a great challenge for the rapid development of enterprises in China. In practice, many enterprises are exploring a long-term incentive mechanism in conformity with Chinese existing policies and regulations. The stock option incentive system is a payment system that stock option stimulates employees to work hard for the long-term development of the company, in the situation of modern enterprises' separation of ownership and management rights.

This system concept into China is in recent years. Thus, in the beginning of creating stock option system in China, we should refer to other countries' experience, considering all the possible risks into legislation, establishing a healthy stock option system with incentive and constraint coexisting, in order to ensure the function of stock option system to effectively play.

\section{Overview of Stock Option}

\section{(1)Concept of Stock Option}

Stock option is a long-term payment incentive mechanism, which is agreed between company and incentive objects, in a certain period, if the incentive objects realize the expected performance, then he can have rights to purchase a certain quantity of company stock according to the current stock price, and also he can not buy stocks.

\section{(2)Legal Nature of Stock Option}

As the company asset owners, they implement a long-term incentive payment system for enterprise operators, and option nature is the beneficiary rights. The author agrees with the right to benefit claims, but it needs to emphasize that, this benefit rights should define from new rights perspective.

First, traditional civil rights don't have the concept of benefit right, but in trust law, insurance law, it is involved with benefit right. From the provision of trust law and insurance law, the benefit right has the following features: (1) Benefit right can be produced by self-benefit contract and can also be produced by other benefit contract. And, benefit right is more likely to be the third party's rights outside the contract. (2)The benefit right is pure request right, and its implementation doesn't need to pay the price.

Second, stock option can take enjoying option interests as the feature, but this option benefit has risks. Because option price is fixed, after the rights, if the company performance is excellent and the stock price increases, the exercise price and market price differential is awarded to the people's income, and operators can gain the margin. On the otherhand, the stock price falls, it will have spread loss.

Third, rights is development concept. Rights type is the gradually formed and found a certain right to be protected in law development process, through legislation or legal precedent theory to give its legal force to make it become the right. As the stock option is hard to be positioning in traditional right system, it should be seen as a new right in commercial law or company law.

\section{Theoretical Basis Analysis of Stock Option Incentive System}

\section{(1) Human Capital Theory}

\section{1) Overview of Human Capital.}

Human capital theory breaks through the constraint of traditional theory capital is only material capital, which divides capital into human capital and material capital.

\section{2) Stock Option and Human Capital Theory.}

Undertaking the above description, it ad mits that human capital and material capital are existing creating wealth capital in company operation. The owner of human capital is the operator in the company. The person has the production element rights and should have corresponding rights. It mentally admits human labor is a capital, and it must admit that operator is human capital, which is human capital ownership, and it should admit and emphasize 
human capital ownership and material capital ownership equality, and human capital owner should have residual claim and decision right. Through stock option system, it makes operator have some option of enterprise, which is the affirmation of their human capital role and recognition.

\section{(2) Company Governance Structure Theory}

Company governance structure is the relevant company operation and right allocation system arrangement between shareholders, creditors, employees and managers .

Traditional company governance structure is to form mutual balance relationship between shareholders, board of directors and managers' responsibility division, in order to realize the final control of company of material capital owner. But the reality is that company operation control right is grasped by senior manager, which is constant separation between ownership and control right, especially in large-scaled open share company, due to the decentralized share holding, increasing executive power has the risk of damaging material capital owner's interests.

\section{Main Content of Stock Option System}

\section{(1)Client of Stock Option System}

In stock option system, the involved clients mainly include the authorized person and the benefit person. The authorized person is also called the implementation main body of stock option, which refers to the company or enterprise according to stock option plan to grant its stock option to the benefit person. The benefit person is also called option benefit person, the authorized object or stock option implementation object. The benefit pers on is relative to authorized person. In stock option relation, the beneficiary is actually the stock option right owner or holder. The beneficiary has the right within the prescribed time limit and amount, to propose exercise requirement to licensing companies.

\section{(2)Stock Option Obtaining}

\section{1) Fabrication of Stock Option Plan.}

The obtained basis for stock option is stock option plan. The stock option plan is composed of a series of documents, generally including: stock option contract, company established performance appraisal system, law firms' law opinions for stock option plan, independent financial consultant's effective opinion for stock option plan and independent financial consultant's performance evaluation opinion.

\section{2)Implementation of Stock Option Plan.}

The implementation of stock option plan refers to the authorized person makes authorization according to stock option plan for implementation object. Through authorizing the beneficiary, it realizes the obtaining and holding of stock option, and it has rights to use the agreed price to purchase a certain amount of the company's stock.

\section{(3) Stock Option Implementation}

\section{1)Implementation Expression}

Stock option implementation is abbreviated as exercise, which refers to option changes into share or share rights. The relative man of exercise is licensing company. Requested by stock option person, the licensing company has the obligation to deliver the stocks. Exercise is as the request behavior, and it needs exercise to show. This exercise means it must be valid within the time. Generally in 3 or 5 years, but in reality it is agreed to 10 years. Over the vesting period, the stock option will automatically lapse.

\section{2) Exercise Price}

The reason of controlling exercise price is that stock option is actually to distribute part of the company profit to option person. Too low exercise price will damage the stakeholders' benefit, and low exercise price will make stock option become "free lunch", without having stimulation role. In "listed company share incentive management method" in China, The price of stock option exercise should not be less than: (1)the equity incentive plan draft abstract release' previous foot company stock closing price. (2)the equity incentive plan draft abstract release's previous 30 trading days' company underlying stock average closing price.

\section{3) Exercise Method}

Exercise method has cash purchase and non-cash exercise. Non-cash exercise method is mainly share exchange, daily sales and promissory notes lending practice. Stock option normally needs cash purchase, unless the statutory stock option, or a resolution of the board of directors, or specifically agreed by option agreement.

\section{4) Sales Restrictions}

After the operators' exercise, it can have holding and cash choice. But in order to maintain the stable management in the company and maintain the interests of the common investors, the operators should not sell their stock option immediately according to the agreed exercise, and its share holding cash should be constraint term or lock up period.

\section{5) Share Source}

In practice, it mainly has three situations, namely, it can reserve option in the amount of shares issued, but also repurchased from second-hand market, and obtained from re-issuance. Generally speaking, rich companies can repurchase to solve stock source, and growing companies prefer to issue new shares. 


\section{Advantage and Disadvantage Analysis of Stock Option System}

\section{(1) Advantages of Stock Option System}

As one of important measures of stimulating company staff's work enthusiasm, stock option has the following advantages: (1)Company has no incentive cost and cash pressure. (2)Incentive object has small fund pressure. (3)Simple operation: compared with limited shares, this mode is that as long as the both parties agree the exercise performance and exercise price, and the incentive object exercise, and the company sells shares to him, and it doesn't need to manage other things. (4)Share increase sometimes can be large, thus its incentive strength is larger than bonus, and it has great temptation for incentive object. (5) The incentive object return is completely determined by market, and even someone feel income and contribution are not proper, and it is hard to say. (6)The equity link makes the incentive object and shareholders' interest agree to a certa in extent, at least, the share increase is good for both parties. (7)Compared with salary and bonus incentive, the incentive role time is longer, generally up to 3-5 years, and the company has no cash pressure. (8)Compared with staff holding share, as incentive object should first do the performance, he can obtain the shares, and the company and shareholders are not worried to give shares without incentive.

\section{(2) Disadvantages of Stock Option System}

Its disadvantages are mainly (1)The incentive income rationality depends on the effectiveness of capital market. (2)Reward and without penalty. The incentive object of stock option has no cost output before exercise, with low risk. (3)If there is no lockups or lock up period is short, it will easily cause operators to pursue share price of short-term act. (4)The high yield of this mode may induce the management accounting cost or even executives quit to throw stock to obtain profit.

\section{References}

[1] Wang Pusong. Reflection on Chinese listed company establishing stock option incentive system, from "Shanghai Economics Research". 2004.4

[2] Shi Huirong. Legal analysis of stock option, from "Guangdong Social Science", 2004.1

[3] Chen Wen. Equity incentive and company governance law practice. Law Press. 2005.1.1

[4] Xu Haifeng. Stock option. People's Court Press. 2005

[5] Chen Hong. China implementing stock option system's legal obstacles and countermeasures, from "Law and Commercial Research". 2002.4

[6] Feng Zibiao. Human capital operation theory. Economic and Science Press. 2000

[7] Zhang Gang. Human capital, organization capital and organization innovation, from "Science Research". 2000.1

[8] Qingmu Yanchang et al. Analysis on economic system comparison system. Wei Jianing translated. Chinese Development Press. 1999

[9] Wang Pusong. Reflection on Chinese listed company establishing stock option incentive system, from "Shanghai Economics Research". 2004.4 